\title{
Type 2 diabetes: is there any relation between poor control and bone metabolism?
}

\author{
André G Daher Vianna, Laiza Tabisz , Claudio Silva de Lacerda, Luciana Muniz Pechmann, Michelle Garcia Polesel, \\ Emerson Cestari Marino, Fellype Barreto
}

From 20th Brazilian Diabetes Society Congress

Porto Alegre, Brazil. 11-18 November 2015

\section{Background}

Numerous evidences suggest that there is a relation between glycemic control and bone fractures in type 2 diabetes individuals. Poorly controlled patients with high blood sugar levels could show higher risk of osteoporosis and/or injuries.

\section{Objective}

This study aims to compare the levels of glycemic control with the serum levels of bone formation and resorpotion markers and the bone mineral density (BMD) in female type 2 diabetes individuals, after menopause.

\section{Materials and methods}

A cross sectional evaluation of 41 female type 2 diabetes individuals was performed. Mean age was $62 \pm 5.91 \mathrm{yrs}$. (mean \pm SD), time of T2D diagnosis $10.15 \pm 6.61$ yrs., $\mathrm{BMI}=32.76 \pm 6.32$. All individuals only used metformin as the anti-diabetic treatment. The glycated hemoglobin (HbA1c) levels were compared to the bone formation markers P1NP and osteocalcin (OC), plus the bone resorption marker CTX as well as lumbar spine, femoral neck and total femoral BMD. Pearson correlation analysis was applied for the total sample, plus comparison between the mean of the groups comprised of quartile 1 (Q1; better control) of HbA1c and quartile 4 (Q4; worse control), through $\mathrm{t}$-test.

\section{Results}

The mean of HbA1c was significantly different between the groups Q1 and Q4 (6.7 \pm 0.001 vs. $8.1 \pm 0.003 \%$ $(\mathrm{p}<0.001))$. Neither significant correlations nor differences between groups Q1 and Q4 were found related to the

\footnotetext{
* Correspondence: laizatabisz@gmail.com
} Hospital Da Cruz Vermelha, Curitiba, Brazil
HbA1c and P1NP levels $(r=0.07 ; \mathrm{p}=0.908), \mathrm{OC}(\mathrm{r}=-0.12$; $\mathrm{p}=0.388)$, CTX $(\mathrm{r}=-0.02 ; \mathrm{p}=0.853)$, lumber spine BMD $(\mathrm{r}=0.160 ; \mathrm{p}=0.671)$, femoral neck BMD $(\mathrm{r}=0.08 ; \mathrm{p}=0.822)$ or total femoral BMD $(\mathrm{r}=0.10 \mathrm{p}=0.575)$.

\section{Conclusion}

We found no significant correlation between levels of glycated hemoglobin and bone formation and resorpotion markers and bone mineral density. There was no difference even when the extreme glycemic control groups were compared.

Published: 11 November 2015

doi:10.1186/1758-5996-7-S1-A60

Cite this article as: Vianna et al:: Type 2 diabetes: is there any relation between poor control and bone metabolism? Diabetology \& Metabolic Syndrome 2015 7(Suppl 1):A60.
Submit your next manuscript to BioMed Central and take full advantage of:

- Convenient online submission

- Thorough peer review

- No space constraints or color figure charges

- Immediate publication on acceptance

- Inclusion in PubMed, CAS, Scopus and Google Scholar

- Research which is freely available for redistribution

Submit your manuscript at www.biomedcentral.com/submit
() Biomed Central

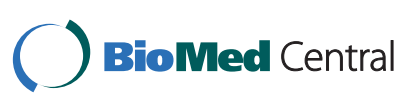

